\title{
OECD DAC 성평등네트워크(GENDERNET) 회의결과
}

개발원조위원회(DAC) 산하 성평등 네트워크(GENDERNET) 회의가 2009.10.22-23간 파리 $\mathrm{OECD}$ 본부에서 개최되었다. 본 회의에서는 GENDERNET의 향후 작업방향, 성평등과 원조 효과 제고, 여성의 경제적 역량강화 등이 논의되었다. 동 회의에는 $\mathrm{KOICA}$ 및 여성정책연구원 으로 구성된 대표단이 참석하여 아래와 같이 회의 주요 내용을 정리, 보고하였다.

\section{I. 핵심 요지}

원조효과성 제고를 위해 아크라행동계획(AAA) 이행에서의 Gender 관점 통합과 세계 경제위기에 서 여성의 경제적 역량 강화를 위한 “작업팀”을 발족하고, 작업팀의 효과적 작업을 위한 정책적 . 실무적 차원의 논의를 활발히 진행하였음.

- DAC Reflection Group의 권고사항에 부응하여, DAC 대내외의 관련기관과 전문가 그룹, 민간 부문과의 긴밀한 공조 - 협력을 확대하고, cross-cutting 이슈로서의 Gender와 다른 주요 개발 이슈와의 접목을 통해 시너지 효과를 도출해 내는 것이 강조됨. 특히, 기후변화와 빈곤퇴치와 같 은 글로벌 공공재가 개발목표 달성과 밀접하게 연관되어 있음에 따라 글로벌 공공재 논의에 있어 Gender 관점의 통합이 필요하다는 데 의견을 같이함.

세계 경제 · 식량위기, 신흥 공여국의 성장과 다양한 개발파트너의 참여 확대 등 급변하는 개발환경 에서 발생하는 새로운 과제와 도전에 부응하기 위해 GENDERNET의 변화가 필요하다는 데 공감 함. GENDERNET이 정책대화의 장(platform for policy dialogue)을 마련하는 역할을 수행해야 함. 


\section{II. 상세 논의 요지}

\section{1. 글로벌 공공재(GPG)와 개발을 위한 정책일관성(PCD)의 Gender 통합}

\section{가. 통합 매트릭스 개발}

(사무국 배경 설명) 10.19 일 개최된 $\mathrm{DAC}$ 정책국장회의에서는 향후 $\mathrm{DAC}$ 의 우선 작업분야로 “Global equitable and sustainable development in a post-crisis world” 매트릭스에 합의 함. (GPG와 PCD가 통합된 형태)

- 4개의 정책 부문은 경제성장 및 빈곤(Economic Growth \& Poverty), 기후변화 및 인간이 지 구에 미치는 영향(Climate and the Human Impact on the Planet), 분쟁 및 취약성(Conflict and Fragility) 및 개발을 위한 재원구조(Financial Architecture for Development)임.

- GPG와 PCD의 효과적인 통합을 위해 Gender, 인권, 거버넌스, 반부패 이슈를 cross-cutting work로 설정하여 통합작업에 적용하고, $\mathrm{DAC}$ 의 핵심 강점인 동료평가, 통계, 원조효과성 부문을 기반으로 작업 수행 예정임.

\section{나. 글로벌 공공재와 Gender}

$\mathrm{DAC}$ 제 1 작업팀은 글로벌 공공재를 모든 국가, 즉 모든 사람에게 혜택을 주는 자원으로 정의하고, 국가 공공재(national public goods)는 한 국가의 모든 시민에게 혜택을 주는 자원으로 정의함.

GENDERNET 참가자들은 국가 공공재로서의 성평등이 국제적 수준에서 spill-over 효과를 내고 글로벌 공공재와 개발 목표 달성 논의시 Gender 관점의 도입점(entry points) 모색의 필요성에 공 감함.

\section{2. 변화하는 개발환경에서의 GENDERNET의 역할}

참가자들은 GENDERNET이 MDG 달성과 원조효과성 제고, DAC reflection group의 권고에 부응 하는 현장 수준(field level)에서 지식의 전파와 상호학습 강화, 회원국과 다양한 개발파트너와의 활발 한 공조 모색 등 개발목표 달성에 중요한 기여를 해왔다는 데 공감. 또한 BRICs, 인도네시아 및 남아 공과 같은 신흥 공여국의 성장과 한국의 DAC 가입, G20의 영향력 확대 등 급변하는 개발환경이 요 구하는 새로운 과제와 도전에 부응하기 위해 GENDERNET도 변화가 요구된다는 데 인식을 같이함. 
GENDERNET이 정책 대화의 장(platform for policy dialogue)을 마련하는 역할이 더욱 강조되어 야 하고, Gender 관점 통합시 성평등이 보다 가시적이고 명시적으로 이루어지도록 하는 것이 긴요 하다는데 의견을 같이함.

\section{AAA 이행(AAA Implementation)부문 TF 논의}

\section{가. DAC 산하작업반의 AAA 이행 현황}

사무국의 DAC 원조효과작업반(WP-EFF) 담당관은 국가 수준(country level)에서의 AAA 달성과 $\mathrm{HLF}-4$ 의제의 Gender 관점 통합이 원조효과 제고에 매우 중요함을 강조.

\section{나. GENDERNET 작업 현황 및 성과}

GENDERNET 사무국은 2007-8년간 영국, 노르웨이 등 공여국들과 Gender, 인권, 참여확대 (inclusion) 이슈에 대한 공동 연구를 수행한 바, 파리선언이 관리차원에서는 많은 성과를 보였으 나, 특히 성평등 달성과 같은 결과 차원의 성과는 미미한 것으로 결론지었다고 보고함.

$\mathrm{WP}-\mathrm{EFF}$ 성과평가 클러스터측은 GENDERNET과 공동으로 2011년 실시 예정인 3차 평가조사시 Gender 관점을 통합하기 위한 entry point를 모색하고 있다고 하고, 기존 평가지표틀 안에서 공여 국이 자발적으로 실시할 3 개(개발전략의 주인의식, 성과관리를 위한 모니터링 프레임워크, 공약이 행의 상호책임성 부문)의 평가지표를 제시함.

\section{4. 여성의 경제적 역량 강화 부문 TF 논의}

\section{가. 여성의 경제적 역량 강화를 위한 공조 노력}

GENDERNET 사무국은 POVNET의 pro-poor growth를 위한 역량강화 TF와의 공조를 통해 빈 곤층 여성들의 경제적 역량 강화 작업과 전반적인 pro-poor growth 작업에 Gender 관점 통합을 위한 사례연구, 포괄적인 정책 가이드라인 제정 등의 공동 성과물을 산출할 계획임을 밝힘. 또한, 내년 UN IANWGE와의 워크숍을 개최하여 여성의 경제적 역량 강화, 주인의식 강화, 상호책무성 관련 사항에 대해 논의하는 등 DAC 대내외 관련 기관과 민간, 학계와의 긴밀한 공조를 강화하고 있 다고 보고함. 


\section{나. Gender 관점의 도입점 확대 모색}

세계은행은 총재의 강력한 정치적 의지를 바탕으로 GENDERNET과 협력하여 세계은행 활동에 Gender 관점을 접목하기 위한 entry point 확보 노력을 기울이고 있다고 함. 그 일환으로 MDG 3 번 양성평등 증진 목표 달성을 위해 2007년부터 4개년 사업인 Gender Action Plan 이니셔티브를 수행 중임.

- 구체적 성과의 일례로 세계은행 IDA 대상 국가의 지역개발 사업의 $75 \%$ 이상이 성인지적으로 계 획을 수립하고, $75 \%$ 이상의 토지 정책 및 제도 사업은 성 분석을 실시하는 목표를 수립함.

\section{GENDERNET 기타 활동내용}

\section{가. 분쟁 및 취약국 지원 확대}

2010년은 분쟁 및 취약국 내 여성들의 권익을 보호하기 위한 UN 결의문 1325 의 채택 10주년이 되는 해로서 이를 기념하기 위한 회원국 및 산하작업반의 다양한 활동이 소개됨. DAC 산하 INCAF 는 평화구축 · 국가재건 · 안보의 부문의 가이드라인에 Gender 관점을 강력하게 통합시키기 위한 노력을 기울이고 있음.

\section{나. UN aid architecture 개혁과 통합적 Gender 개체}

UNIFEM은 현 UN 시스템이 통합적 Gender 개체(consolidated gender entity)로서 정책일관성과 상호연관성을 도모하기 위해 전례없이 강력한 개혁을 추진 중임을 소개함. GENDERNET 사무국 은 원조효과성 뿐만 아니라 $\mathrm{MDG}$ 이후 국제사회의 공동 목표로서의 여성의 권익 보호와 참여를 위 한 UN의 기여를 기대한다고 밝힘. 한편, 캐나다는 UN 시스템내의 성 인지적인 aid architecture 의 개편을 환영하면서 GENDERNET이 독립적으로 작업하지 않고, DAC 외부에서 진행되는 논의 와 추세에 맞추어 협력해야함을 강조함.

\section{다. 2011-12 GENDERNET 작업 방향}

사무국은 현재 GENDERNET이 여타 DAC 산하작업반 및 회원국, $\mathrm{DAC}$ 외부의 관련 기관 및 전문가들과 의 긴밀한 협력과 공조를 통해 Gender 부문의 작업에 시너지를 만들어내고 있다고 하면서, 원조효과성 . 동료평가 - 통계 부문의 작업 강화, 2 개 $\mathrm{TF}$ 의 외부 전문가와의 지속적인 협력 추진을 향후 과제로 제시함. 